\title{
Severe Methemoglobinemia Due to Nitrite Intoxication in a Child Who was Misdiagnosed with Sepsis
}

\author{
Yanlışı|ıla Sepsis Olarak Değerlendirilen Bir Çocukta Nitrit Intoksikasyonuna Bağlı Ciddi \\ Methemoglobinemi
}

\author{
Aykut Çağlar1, Anıl Er¹, Utku Karaarslan², Emel Ulusoy¹, Fatma Akgül11, Gözde İnci1 ${ }^{1}$, Tolga Fikri Köroğlu², Murat Duman¹, Durgül Yılmaz1 \\ ${ }_{1}^{1}$ Dokuz Eylül University Faculty of Medicine, Department of Pediatric Emergency Care, Izmir, Turkey \\ ${ }^{2}$ Dokuz Eylül University Faculty of Medicine, Department of Pediatric Intensive Care Unite, Izmir, Turkey
}

\section{Abstract}

We present here, a child with an extremely high methemoglobin level caused by inadvertently prepared sodium nitrite and potassium nitrite by a pharmacist. On physical examination, he had tachycardia and tachypnea. He had cyanosis, and mottled and blue-gray skin color. Oxygen saturation was $85 \%$ on room air. He was intubated due to seizure and arterial hypotension. Although he had no history of cyanotic heart disease, cyanosis was resistant to $100 \%$ oxygen therapy. Venous blood gas sampling revealed metabolic acidosis and methemoglobinemia (86.2\%). Methylene blue dye at a dose of 2 $\mathrm{mg} / \mathrm{kg}$ and ascorbic acid at a dose of $500 \mathrm{mg}$ were administered intravenously and the clinical improvement was observed in 12 hours. Methemoglobinemia can cause severe systemic findings and death. The clinical findings can mimic septic shock. Emergency physicians should have awareness of methemoglobinemia in patients with cyanosis unresponsive to oxygen therapy.

Keywords: Emergency, intoxication, pediatrics, nitrite, methemoglobinemia

\section{Öz}

Bu yazıda eczacı tarafından yanlış hazırlanmış ilaç alımı sonrası, sodyum nitrit ve potasyum nitrite bağlı ciddi bir methemoglobinemi olgusu sunulmaktadır. Illk fizik muayenesinde hasta taşikardik ve takipneikdi. Hastanın siyanozu ve gri - mavi bir deri rengi vardı. Bilinen bir kardiyak hastalığı olmamasına rağmen, \%100 oksijen ile satürasyonu \%85 idi. Geldiğinde siyanoz, bilinç değişikliği, konvülziyonu ve hipotansiyonu olan hasta entübe edildi. Alınan venöz kan gazında methemoglobinemi $(\% 86,2)$ ve metabolik asidoz saptandı. Hastaya metilen mavisi $2 \mathrm{mg} / \mathrm{kg}$ intravenöz ve $500 \mathrm{mg}$ intravenöz askorbik asit uygulandı. Takibinde methemoglobin seviyesi 12 saat içinde tedrici olarak geriledi ve klinik düzelme görüldü. Methemoglobinemi, ciddi bulgulara ve ölüme neden olabilecek bir durumdur. Klinik bulgular septik şok ile karışabilmektedir. Acil hekimleri oksijene yanıt vermeyen siyanoz durumlarında methemoglobinemi olabileceğini mutlaka düşünmelidir.

Anahtar Kelimeler: Acil, zehirlenme, çocuk, nitrit, methemoglobinemi

\section{Introduction}

Methemoglobinemia is a rare condition which refers to increased plasma methemoglobin (MetHb) levels due to oxidation of ferrous iron $\left(\mathrm{Fe}^{++}\right)$to ferric iron $\left(\mathrm{Fe}^{++}\right)$within hemoglobin 1. Accidental nitrate or nitrite intoxication is one of the common causes of severe methemoglobinemia and it is usually related to an oxidizing agent which comprises nitrites, such as water, drugs and chemicals. 1 There are few reports about severe methemoglobinemia due to nitrite ingestion. $2-6$ While levels above $50 \%$ may cause severe systemic findings, such as tachycardia, tachypnea, altered state of consciousness, and coma, levels above $70 \%$ may cause death 1 (Table 1). In reports of the cases of surviving patients, the highest reported level of MetHb was 94\%.7 We present here, a child with an extremely high level of MetHb due to inadvertently prepared drug by a pharmacist. Additionally, he was previously misdiagnosed with sepsis and urinary tract infection and was barely diagnosed in the second episode. In this paper, since it can be life-threatening, we aim to emphasize the importance of diagnosis and proper management of methemoglobinemia.

\section{Case}

A two-year-old boy with complaints of vomiting, rapid breathing and being pale was referred to our emergency 
department with the pre-diagnosis of septic shock. On admission, he was conscious and had the signs of respiratory distress such as tachypnea, cyanosis and agitation. While we were performing general assessments, he had a generalized seizure. On physical examination, he had tachycardia (165 beats/min) and his blood pressure was $117 / 80 \mathrm{mmHg}$. His respiratory rate was $45 / \mathrm{min}$ and the chest was clear. He had cyanosis and, mottled and blue-gray skin color (Figure 1). Oxygen saturation $\left(\mathrm{SpO}_{2}\right)$ was $85 \%$ on room air while receiving oxygen via non-rebreather mask. Midazolam

\begin{tabular}{|l}
$\begin{array}{l}\text { Table 1. Clinical findings according to methemoglobinemia } \\
\text { levels }\end{array}$ \\
\begin{tabular}{ll} 
MetHb level (\%) & Clinical findings \\
$0-15$ & None \\
$15-30$ & Mild (cyanosis, fatigue, dizziness, headache) \\
$30-50$ & Moderate (weakness, tachypnea, mild dyspnea) \\
$50-70$ & Severe (stupor, comai, convulsions, respiratory \\
& depression, cardiac dysrhythmias and acidosis) \\
$>70$ & Potentially fatal \\
MetHb: Methemoglobinemia \\
\hline
\end{tabular}
\end{tabular}

Table 2. Initial and serial blood gas measurements after the treatment of the patient

\begin{tabular}{|llllll|}
\hline & 0. minute & 30. minute & 1. hour & 2. hour & 4. hour \\
$\mathrm{pH}$ & 6.91 & 7.21 & 7.25 & 7.26 & 7.39 \\
$\mathrm{pCO}_{2}$ & 45.1 & 35.1 & 41.7 & 46.1 & 39.5 \\
$\mathrm{HCO}_{3}$ & 9.5 & 14.0 & 17.4 & 19.4 & 23.7 \\
Lactate & 8.8 & 11.1 & 9.4 & 5.0 & 1.4 \\
MetHb & 86.2 & 67.7 & 43.9 & 24.9 & 3.2 \\
\hline MetHb: Methemoglobin & & & & \\
\hline
\end{tabular}

Table 3. Laboratory parameters of the patient

\begin{tabular}{|ll|}
\hline Laboratory parameters & Values \\
Hemoglobin (g/dL) & 7.6 \\
Hematocrit (\%) & 23.6 \\
MCV (fL) & 64.2 \\
RDW (\%) & 15.1 \\
Platelet (103/mL) & 338 \\
AST (U/L) & 28 \\
ALT (U/L) & 20 \\
BUN (mg/dL) & 12.7 \\
Kreatinin (mg/dL) & 0.39 \\
Troponin - I (ng/mL) & 0.8 \\
CK-MB (ng/mL) & 10.3 \\
MCV: Mean corpuscular volume, RDW: Red cell distribution width, BUN: Blood urea \\
nitrogen, CK-MB: Creatinine kinase MB fraction, AST: Aspartate aminotransferase, \\
ALT: Alanine aminotransferase
\end{tabular}

was administered at a dose of $0.1 \mathrm{mg} / \mathrm{kg}$ intravenously to control seizure. He was intubated immediately for refractory cyanosis, but we did not observe increment in $\mathrm{SpO}_{2}$ and improvement in cyanosis. Therefore, blood gas sampling and MetHb level were obtained and metabolic acidosis and methemoglobinemia were determined (Table 2). Methylene blue and ascorbic acid were administered at a dose of $2 \mathrm{mg} /$ $\mathrm{kg}$ and $500 \mathrm{mg}$ intravenously, respectively. $1 \mathrm{mEq} / \mathrm{kg}$ sodium bicarbonate was given intravenously for metabolic acidosis. $20 \mathrm{~mL} / \mathrm{kg}$ saline bolus was administered. On follow-up, fluid refractory hypotension $(77 / 42 \mathrm{mmHg})$ was observed. He had reduced peripheral perfusion and muffled heart sounds. Therefore, dobutamine $(10 \mathrm{mcg} / \mathrm{kg} / \mathrm{min})$ and adrenalin $(0.1$ $\mathrm{mcg} / \mathrm{kg} / \mathrm{min}$ ) infusions were administered and titrated to 0.3 $\mathrm{mcg} / \mathrm{kg} / \mathrm{min}$

Laboratory parameters of the patient are summarized in Table 3. His renal and liver function tests were normal, and cardiac enzymes were slightly elevated. He had anemia. Nitrite reaction was positive in urine screen test. In the medical history, the patient had been followed by a nephrologist with the diagnosis of medullary sponge kidney and he had been used Shohl's solution (sodium citrate and potassium citrate) for the treatment. Three days earlier, he had presented at a pediatric emergency department in a different center with the same signs and symptoms. He had been intubated and transferred to pediatric intensive care unit immediately and treated for urinary tract infection and sepsis. He was discharged with recovery after three days. Shohl's solution was not administered to the patient during that time. After being discharged, he took Shohl's solution just for one dosage. Thus, his family suspected about Shohl's solution and we realized that the pharmacist had prepared Shohl's solution with nitrite in lieu of citrate.

With the history and physical examination findings, the diagnosis of methemoglobinemia due to nitrite intoxication was made. After 12 hours, we obtained normal oxygen saturation and there was no requirement for inotrope agents;

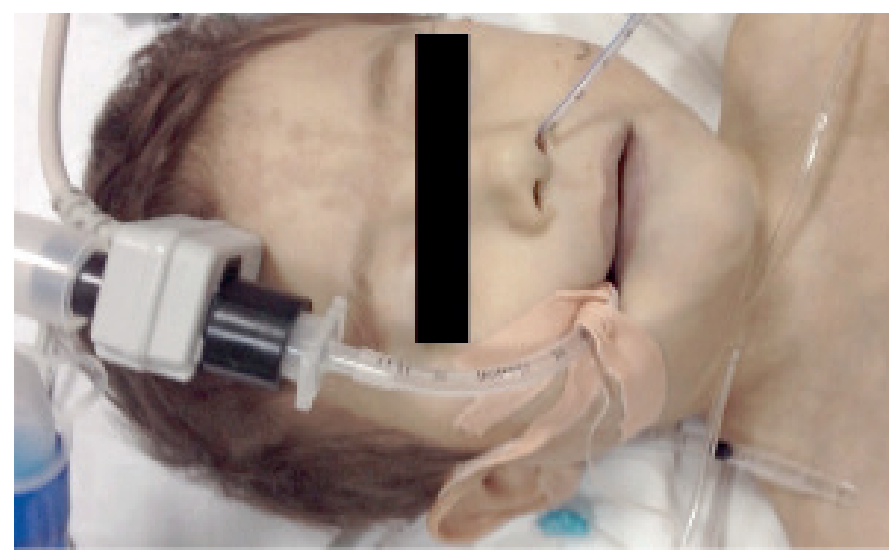

Figure 1. Mottled and blue - gray color of skin 
MetHb and lactate levels were decreased gradually. After 24 hours, he was entirely normal and had no symptoms.

\section{Discussion}

Nitrite intoxication is one of the most common causes of acquired methemoglobinemia and usually secondary to accidental ingestion. In this case, the main reason of methemoglobinemia was a prescription error due to poor legibility of handwriting. Prescription errors are an important issue and may cause life-threatening events as in our case.8,9 Computerized systems can be a preventive method for prescription errors.

Clinical features of methemoglobinemia vary depending on the MetHb level. Levels above $70 \%$ can cause lifethreatening events and death. 1 To our knowledge, the MetHb level (86.2\%) in this case was the highest among pediatric methemoglobinemia survivors. In the first episode, our patient was intubated and had been treated for sepsis and urinary tract infection due to positive reaction for nitrite in urine dipstick test. Although we had not any information to confirm this situation, we thought that our patient had had a slightly higher MetHb level in the first episode and the patient's MetHb level had decreased gradually because natural reduction of the oxidizing agent had not been given during hospital stay. On the contrary, MetHb levels may increase in patients with sepsis due to release of nitric oxide10; methemoglobinemia may be confused with sepsis if the patient has fever or hypothermia. ${ }^{11}$ Additionally, this patient had been misdiagnosed with urinary tract infection due to positive reaction to nitrite in urine dipstick test. Urinary dipstick test can be useful in identifying nitrite ingestion. 12 Although in the second episode, his urine was positive for nitrite too; all these factors might show that he was misdiagnosed as sepsis.

Arterial saturation was $85 \%$ and there was no improvement with oxygen therapy. This phenomenon can be explained by absorbance ratio of MetHb. Pulse oximetry machines measure absorbance of hemoglobin at two wavelengths (660 and $940 \mathrm{~nm}$ ). The ratio of these measurements (A660/A940) corresponds to saturation that previously calibrated from healthy volunteers' pulse oximetry data. The absorbance ratio of 0.43 corresponds to $100 \%$ saturation whereas a ratio of 3.4 corresponds to $0 \%$. If the absorbance ratio is 1.0 , it corresponds to $85 \%$ oxygen saturation. MetHb absorbs lights equally at two wavelengths. If the MetHb level exceeds above $35 \%$, the ratio is 1 and therefore it corresponds to $85 \%$ oxygen saturation. 12 Therefore, if the patients have no cyanotic cardiac disease and have $85 \%$ of $\mathrm{SpO}_{2}$, emergency physicians must consider a MetHb level above 35\%.

The most widely known treatment is methylene blue dye which reduces MetHb levels gradually within less than one hour. If the patient has severe symptoms or a MetHb level above $30 \%$, the patient should be treated immediately with methylene blue 1. We gave methylene blue and ascorbic acid and an improvement was rapidly observed. Although there are alternative treatments ( $\mathrm{N}$ - acetylcysteine and cimetidine) to methylene blue dye ${ }^{13}$, we suggest that early administration of methylene blue was the most important point in this case for survival and must be available in all emergency room. Methemoglobinemia can cause functional anemia. If the patient has anemia, the clinical deterioration may be more obvious. ${ }^{14}$ Our patient had also microcytic anemia, but there was no need for transfusion because of rapid response to methylene blue treatment.

In conclusion, nitrite intoxication can cause severe methemoglobinemia and may be confused with sepsis and urinary tract infection. Awareness of emergency physicians about methemoglobinemia in patients with cyanosis unresponsive to oxygen can be lifesaving.

\section{Ethics}

Informed Consent: Consent form was filled out by all participants.

Peer-review: Externally peer-reviewed.

\section{Authorship Contributions}

Surgical and Medical Practices: Aykut Çağlar, Utku Karaarslan, Emel Ulusoy, Fatma Akgül, Durgül Yılmaz, Murat Duman, Tolga Fikri Köroğlu, Concept: Aykut Çağlar, Utku Karaarslan, Emel Ulusoy, Fatma Akgül, Durgül Yılmaz, Murat Duman, Tolga Fikri Köroğlu, Design: Aykut Çağlar, Utku Karaarslan, Emel Ulusoy, Fatma Akgül, Durgül Yılmaz, Murat Duman, Tolga Fikri Köroğlu, Data Collection or Processing: Aykut Çağlar, Utku Karaarslan, Emel Ulusoy, Fatma Akgül, Analysis or Interpretation: Aykut Çağlar, Utku Karaarslan, Emel Ulusoy, Fatma Akgül, Durgül Yılmaz, Murat Duman, Tolga Fikri Köroğlu, Gözde İnci, Literature Search: Aykut Çağlar, Utku Karaarslan, Emel Ulusoy, Fatma Akgül, Anıl Er, Writing: Aykut Çağlar.

Conflict of Interest: No conflict of interest was declared by the authors.

Financial Disclosure: The authors declared that this study received no financial support. 


\section{References}

1. Wright RO, Lewander WJ, Woolf AD. Methemoglobinemia: etiology, pharmacology, and clinical management. Ann Emerg Med. 1999;34:646-56.

2. Gowans WJ. Fatal methaemoglobinaemia in a dental nurse. A case of sodium nitrite poisoning. Br J Gen Pract. 1990;40:470-1.

3. Harvey JW, Keitt AS. Studies of the efficacy and potential hazards of methylene blue therapy in aniline-induced methaemoglobinaemia. Br J Haematol. 1983;54:29-41.

4. Wilkerson RG. Getting the blues at a rock concert: a case of severe methaemoglobinaemia. Emerg Med Australas. 2010;22:466-9.

5. Kaplan A, Smith C, Promnitz DA, Joffe BI, Seftel HC Methaemoglobinaemia due to accidental sodium nitrite poisoning. Report of 10 cases. S Afr Med J. 1990;77:300-1.

6. Freeman L, Wolford RW. Methemoglobinemia secondary to cleaning solution ingestion. J Emerg Med. 1996;14:599-601.
7. Edwards RJ, Ujma J. Extreme methaemoglobinaemia secondary to recreational use of amyl nitrite. J Accid Emerg Med. 1995;12:13842.

8. Tully MP. Prescribing errors in hospital practice. Br J Clin Pharmacol. 2012;74:668-75.

9. Velo GP, Minuz P. Medication errors: prescribing faults and prescription errors. Br J Clin Pharmacol. 2009;67:624-8.

10. Rehman HU. Methemoglobinemia. West J Med. 2001;175:193-6.

11. Khemiri M, Labassi A, Jr., Tlili $Y$, Jr., Barsaoui S. Severe toxic methemoglobinemia mimicking septic shock in an infant. Int Emerg Nurs. 2009;17:181-3.

12. Haymond S, Cariappa R, Eby CS, Scott MG. Laboratory assessment of oxygenation in methemoglobinemia. Clin Chem. 2005;51:434 44.

13. McCrea S. Methaemoglobinaemia and poisoning. Emerg Nurse. 2001;9:18-22.

14. Camp NE. Methemoglobinemia. J Emerg Nurs. 2007;33:172-4. 